\title{
4. \\ VLADAN DESNICA U IZVORIMA IZ \\ OBITELJSKOG ARHIVA PROFESORA \\ VLADIMIRA RISMONDA ST. IZ SPLITA
}

\section{Vladimir Rismondo}

UDK: 929Desnica, V.:929.52Rismondo(044)

Izvorni znanstveni članak

Sažetak: Obiteljski arhiv splitskog povjesničara i kulturnog pregaoca Vladimira Rismonda st. (Makarska, 11. rujna 1902. - Split, 8. siječnja 1994.) iz Splita pruža obilje fragmentiranih podataka o osobnostima i pojavama koje su obilježile kulturnu, političku i gospodarsku povijest Dalmacije u 19. i 20. stoljeću. Jedna od tih ličnosti je i književnik Vladan Desnica (Zadar, 17. rujna 1905. - Zagreb, 4. ožujka 1967.), koji je s Rismondom dijelio duboko prijateljstvo i značajne dijelove biografije. Ipak, iako su kontakti Desnice i Rismonda bili neupitni i česti, u Rismondovom splitskom arhivu nađeno je tek osam Desničinih pisama i dopisnica te određeni broj dokumenata od sekundarnog značaja. Članak popisuje i elementarno opisuje ove izvore, stavljajući ih pritom u intelektualni kontekst društva „,splitskih kročeanaca“ prije Drugog svjetskog rata, odnosno pobornika ideje „dalmatinskog mediteranizma" nakon rata.

Ključne riječi: Vladan Desnica, Vladimir Rismondo st., obiteljski arhiv, splitski kročeanci, mediteranizam, egzistencijalizam

\section{UvoD}

ledano iz perspektive istraživača, obiteljski arhivi najčešće predstavljaju kaotične, načelno nesređene nakupine nataloženih sjećanja, materijaliziranih u najrazličitijim vrstama dokumenata. Obiteljski arhiv, dakle, u pravom smislu riječi postaje arhivom tek nakon što dostigne racionalnu reorganizaciju koju - prema više ili manje uvriježenom načelu - prati i dosljedna katalogizacija. Arhiv obitelji prof. Vladimira Rismonda iz Splita prolazi kroz sličnu reorganizaciju već dvadesetak godina, a glavni akteri ovog procesa su i neposredni nasljednici materijala: Marica Rismondo-Berket i Mihovil Rismondo, odnosno djeca tvorca arhiva. Određen temeljnim interesima svojeg kreatora, arhiv predstavlja ne- 
pravilni presjek kroz kulturnu povijest Srednje Dalmacije u 19. i 20. stoljeću te se izravno i neizravno dotiče velikog broja obitelji i pojedinaca koji su u tom razdoblju na kulturnom, političkom i gospodarskom planu tvorili identitet regije. Ovdje dakako ne mislimo samo na obitelji Rismondo i Manđer - kojima je prof. Vladimir Rismondo rođenjem pripadao - već i na široki raspon struja koje su određivale kulturološku sliku Srednje Dalmacije. ${ }^{1}$

U toj slici (barem prema stanju konkretnog arhiva) jednaki značaj zauzimaju, primjerice, obitelj Smodlaka, na političku ulogu koje u formiranju hrvatskih prostora ne treba podsjećati, prvak dalmatinskog narodnjaštva Natko Nodilo, trogirski kanonik i znanstvenik don Ivo Delalle, ali i, recimo, splitski umjetnički krugovi koje je Rismondo revno pratio čitavih sedam desetljeća. Nabrojili smo tek neke pojave koje se u većim ili manjim fragmentima mogu pratiti kroz tkivo arhiva, a njima svakako treba dodati i Rismondova sjećanja na književnika Vladana Desnicu. Prijateljstvo Vladana Desnice i Vladimira Rismonda, promatrano iz obiteljske perspektive obitelji Rismondo, konačno je zadobilo legendarne dimenzije praćene usmenom predajom. ${ }^{2}$ Ona se mahom sastoji od anegdotalnih crtica koje stvaraju fino, humorom protkano narativno tkivo oko tri različita perioda komunikacije dvojice intelektualaca. Prvi se period odnosi na Desničinu splitsku rezidenciju između dva svjetska rata, drugi na zajedničko vrijeme provedeno u Zadru tijekom ratne talijanske okupacije, da bi treći period bio određen Desničinim poslijeratnim preseljenjem u Zagreb, odnosno vremenom koje završava Desničinom smrću 1967. godine.

Prof. Vladimir Rismondo nadživio je Vladana Desnicu za gotovo tri desetljeća, a njegova smrt 8. siječnja 1994. godine označava i simbolički datum zatvaranja unosa građe u obiteljski arhiv. Zanimljivo je, ipak, primijetiti kako se jedno tako intenzivno prijateljstvo, odnosno intelektualna bliskost - kakva je bila ona između Desnice i Rismonda - u arhivu potonjeg može materijalno potkrijepiti tek s osam izravnih dokaza u vidu Desničinih pisama Rismondu. Ovome treba dodati i tri drugorazredna izvora o kojima će biti riječi kasnije. Razloge za ovako šturu Desničinu prisutnost u arhivu prof. Vladimira Rismonda treba najprije potražiti u kronologiji odnosa. Naime, četvrto desetljeće 20. stoljeća obojica

\footnotetext{
Vladimir Rismondo rodio se 11. rujna 1902. godine u Makarskoj. Maturirao je na splitskoj Klasičnoj gimnaziji, a potom studirao u Beču, Zagrebu i Beogradu. Povijest, komparativnu književnost i povijest umjetnosti konačno je završio na Filozofskom fakultetu u Beogradu, a od 1927. bez prekida je živio u Splitu. Radio je kao profesor opće povijesti, najprije na Realnoj gimnaziji, a od 1946. do 1974. godine na Pedagoškoj akademiji. Također je honorarno predavao opću povijest srednjeg vijeka na Filozofskom fakultetu u Zadru. Prvu pjesmu objavljuje kao gimnazijalac, već 1918. u zagrebačkoj Omladini, a zadnju pjesničku zbirku tiska u izdanju splitskog Književnog kruga 1989. godine. Nakon Drugog svjetskog rata intenzivnije se posvećuje prevođenju s talijanskog i srednjovjekovnog latinskog te objavljivanju kritičkih izdanja dokumenata koji rasvjetljavaju medievalnu povijest srednje Dalmacije, a posebno Splita i Trogira. U tom smislu istaknuto mjesto zauzimaju slijedeći radovi: Pomorski Split druge polovine XIV st. Notarske imbrevijature (Split, 1954.); Toma Arhiđakon, Kronika (Split, 1960. i 1977.); Registar notara Nikolela iz Augubija (Split, 1966.); Trogirsko i splitsko zalede u nekim dokumentima iz druge polovice 14. i početka 15. stoljeća (Zadar, 1976.); Pavao Andreis, Povijest grada Trogira I. (Split, 1977.); Miha Madijev i A. Cutheis, Kronike (Split, 1977.); Vicko Solitro, Povijesni dokumenti o Istri i Dalmaciji (Split, 1989.) te posebno posthumno objavljena Zlatna knjiga grada Splita, koju je priredio s Marinom Berketom, Vedranom Gligom i Ljerkom Šimunković (Split, 1996.). Vladimir Rismondo objavio je i niz eseja, kritika te naslova koji se općenito odnose na dokumentiranje i rasvjetljavanje aktualne kulturne slike srednje Dalmacije u drugoj polovini 20.st. Umro je u Splitu 8. siječnja 1994.

2 U svrhu fiksiranja preostalih obiteljskih sjećanja na prijateljstvo Vladana Desnice s prof. Vadimirom Rismondom, zamolili smo Maricu Rismondo-Berket da ta sjećanja prenese u pisanu formu. U Prilogu donosimo izravni prijepis njezinog pisanog svjedočenja. Razloge za namjerno izostavljanje redakture nalazimo ponajprije u literarnoj, a potom i zgusnutoj faktografskoj vrijednosti samog teksta.
} 
provode u Splitu; potom će razdoblje talijanske okupacije (poglavito 1942. godinu) ponovno zajedno provesti u Zadru u statusu prevoditelja, da bi se u periodu 1943. - 1945. Desnica izolirao najprije u Islamu Grčkom, a potom našao i na oslobođenom teritoriju bez mogućnosti ostvarivanja kontakta. Odatle činjenica kako je svih osam Desničinih pisama datirano u poslijeratno vrijeme, kad se pisac preselio u Zagreb. Također treba dodati da $\mathrm{u}$ arhivu nije nađeno nijedno Rismondovo pismo Desnici, čak ni u nedovršenom stanju. Ukoliko ona postoje (a iz Desničine korespondencije dade se naslutiti kako Rismondo nije bio sklon prečestom javljanju pismenim putem), valja ih potražiti u arhivskim materijalima obitelji Desnica. Na kraju, ali ne i posljednje, nije isključeno da još uvijek ne sasvim sređeno stanje arhiva prof. Vladimira Rismonda prije ili poslije iznjedri nove materijale koje ćemo moći shvatiti u vidu priloga temi.

\section{RASPRAVA}

Prijateljstvo Vladana Desnice i Vladimira Rismonda imalo je svoj intelektualni i vremenski okvir. On se sastojao u gotovo identično prijeđenim etapama intelektualnog sazrijevanja, a podrobnija bi analiza uputila na tri takva koraka. Prvi se sastojao u identičnom - i za pojmove četvrtog desetljeća 20. stoljeća - naprednom prihvaćanju estetike proizašle iz opusa Benedetta Crocea. U tom je smislu Desnica 1938. godine preveo te u izdanju ad hoc stvorenog splitskog izdavača „Kadmos“ i objavio nekoliko Croceovih eseja. ${ }^{3}$ Rismondo se, opet, po završetku Drugog svjetskog rata svojevoljno odrekao općih teorijskih pokušaja te je u klimi koja nije bila sklona građanskoj estetici prikrio svoje „kročeanstvo“, posvetivši se relativno bezopasnom prevođenju srednjovjekovne arhivske građe i kroničarskom praćenju splitske likovne scene.

Druga etapa koju su dvojica subesjednika zajedno prošla dade se opisati kao osvještavanje genius loci pojma mediteranizma u vidu specifičnog poimanja „dalmatinstva“. Doista, promotrimo li korijene ovog - za naše prilike nedovoljno istraženog - kulturnog usmjerenja, naći ćemo kako su, primjerice, Desnica i Rismondo 1935. godine istovremeno objavili tekstove protkane tada tek naslućenim shvaćanjem mediteranizma u Magazinu Sjeverne Dalmacije, koji je uređivao upravo Vladan Desnica. Desnica je, dakle, u tom broju Magazina objavio tekst pod nazivom „Mirko Korolija i njegov kraj“, gdje je dalmatinski identitet definirao suprotstavljanjem dvije kulturne paradigme: „primitivnog narodnog života“ $\mathrm{i}$ „latinskog primorja pod utjecajem Zapada“. ${ }^{4}$ Vladimir Rismondo je tik do Desničinog članka objavio vlastiti programatski tekst pod naslovom „Za jednu dalmatinsku kulturnu orijentaciju“. $\mathrm{Tu}$ je pisac - nešto manje poetski u odnosu na Desnicu te s više osjećaja za povjesničarsku struku kojoj je i sam pripadao - zagovarao dvije komponente „dalmatinstva“: prvo,

3 Benedetto Croce, Eseji iz estetike, Split 1938.

4 Vladan Desnica, „Mirko Korolija i njegov kraj“, Magazin Sjeverne Dalmacije, 2/1935., 117-129.

5 Vladimir Rismondo, „Za jednu dalmatinsku kulturnu orijentaciju“, Magazin Sjeverne Dalmacije, 2/1935., 111116. 


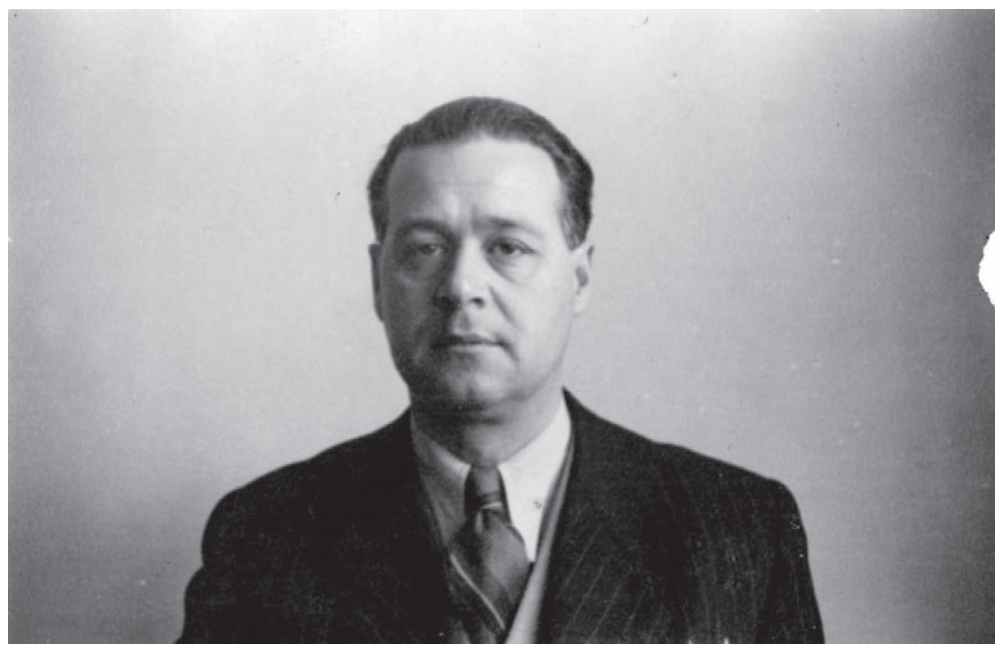

Sl. 1. Vladimir Rismondo početkom 1940-ih

organsko povijesno izrastanje te, drugo, konstruktivističku dimenziju dalmatinskog identiteta koja se gradi od „eupatridskog ustrojstva dalmatinskog seljaštva“ $i$,građanske estetske apsolutnosti mediteranskog duha“. ${ }^{6} \mathrm{Ne}$ računajući činjenicu da će vrlo slične pretpostavke mediteranskog identiteta $\mathrm{u}$ isto vrijeme istraživati te nešto kasnije na daleko široj skali popularizirati znameniti povjesničar Fernand Braudel svojom knjigom La Méditerranée et le Monde Méditerranéen a l'époque de Philippe II. (Pariz, 1949.), u oči upada podudarnost uvjerenja kako Vladana Desnice tako i Vladimira Rismonda o konstruktivističkoj dimenziji dalmatinskog identiteta.

Taj osjećaj za ruralno-urbani konstrukt mediteranskog „dalmatinstva“ obojica će nastaviti graditi i u poslijeratnom vremenu. Desnica je tako 1950. godine objavio roman Zimsko ljetovanje, koji će Mirna Sindičić Sabljo - citirajući ocjenu Krešimira Nemeca - ocijeniti kao prvi značajni udarac socrealističkoj poetici u hrvatskoj književnosti. ${ }^{7}$ Ipak, pravi sadržaj tog iznimnog književnog teksta nalazi se upravo u brodelovskom razumijevanju Mediterana kroz konstruirani sukob urbanog i ruralnog mentaliteta. Vladimir Rismondo je, pak, 1964. godine objavio zbirku kritika i eseja naslovljenu Ljudi i slike Dalmacije. ${ }^{8}$ Tu je sakupio niz ranije objavljenih tekstova kroz koje je najprije maglovito, a potom sve svjesnije i jasnije promovirao razvojnu liniju vlastitog „dalmatinstva“ u razdoblju od 1930. do 1964. godine. Suvremeni će čitatelj u kazalu knjige naći živopisnu galeriju likova koje je Rismondo prepoznavao kao nositelje dalmatinskog identiteta. Likovni umjetnici Antun Zuppa, Ignjat Job, Milan Tolić, Juraj Plančić ili kipar Andrija Krstulović susreću se ondje s književnicima poput Sime Matavulja, Ante Cettinea, Ćire Čičin Šaina, Hranka Smodlake pa i samog Vladana Desnice.

7 Mirna Sindičić SAbljo, „Predodžbe o ruralnoj sredini u Zimskom ljetovanju Vladana Desnice“, Fluminensia, 23/2011., br. 1, 131.

$8 \quad$ Vladimir Rismondo, Ljudi i slike Dalmacije, Split 1964. 
Treća etapa intelektualnog razvoja koju će Vladan Desnica i Vladimir Rismondo podijeliti može se definirati kao razvijanje egzistencijalističkih pozicija. U tom smislu Desnica već 1957. godine objavljuje svoje remek-djelo u formi romana eseja Proljeća Ivana Galeba, a za koje Krešimir Nemec uočava kako se radi o tekstu koji po principu montaže spaja nekoliko vrsta fragmentiranih diskursa. ${ }^{9}$ Pritom je Desnica u romanu uspio ostvariti poziciju autentičnog egzistencijalizma ukorijenjenog u hajdegerovskoj dimenziji vremena („dinamika sjećanja“). Mnogo kasnije u odnosu na Desnicu, Vladimir Rismondo objavio je 1989. godine svoj završni umjetnički credo, i to u formi zbirke pjesama u prozi pod nazivom $\mathrm{Za}$ ustavljeno vrijeme. ${ }^{10}$ Slobodni stih ovdje je u funkciji kontinuiranog taloženja novih slika na početne imaginacijske obrasce, čime se Rismondo u sadržajnom - mada ne i formalnom - smislu posve približava Desničinom romanu Proljeća Ivana Galeba.

Paralelizam dva opisana intelektualna izrastanja čini se, ipak, značajnijim od puke činjenice o prijateljstvu dva dalmatinska intelektualca. Naime, to je prijateljstvo smješteno u još uvijek nedovoljno poznat intelektualni i umjetnički kontekst građanskog Splita i Dalmacije, a koji se - rekli bismo - razvija usporedno s društveno-političkom makrosituacijom. Kronološko određenje ovog konteksta mogli bismo s donje strane omeđiti 1918. godinom, kad Vladimir Rismondo objavljuje prve pjesničke pokušaje pa se time javno deklarira kao intelektualac. ${ }^{11}$ Također se radi o godini u kojoj Dalmacija izlazi iz višestoljetnog venetoaustro-ugarskog egzistencijalnog prostora te ulazi u novo identitetsko okruženje. S druge strane bismo gornju kronološku granicu - nimalo proizvoljno - mogli staviti u 1960. godinu, kad Vladimir Rismondo publicira prijevod Kronike Tome Arhidakona - jednog od temeljnih izvora srednjovjekovne hrvatske povijesti - te tom prilikom objavljuje predgovor kojim jasno iskazuje svoju (ne samo profesionalnu) simpatiju za splitskog klerika i kroničara iz 13. stoljeća. ${ }^{12}$ Doista, Toma Arhiđakon zalagao se za neovisnost splitskog municipalnog tkiva, a pogotovo u kontekstu ruralnog, gradu neprijateljskog hrvatskog zaleđa. Taj antagonizam grada i njegovog zaleđa Rismondo je svakako prepoznao u kontekstu ranijih, ali i sve aktualnijih promišljanja dvojnog dalmatinskog identiteta; ne treba sumnjati ni u činjenicu da se slična konfliktna situacija može iščitati i u Desničinom Zimskom ljetovanju, ali suština problema leži negdje drugdje. Naime, do ranih šezdesetih godina 20. stoljeća u Dalmaciji je stasala cijela generacija ponajprije likovnih umjetnika koji su postali svjesni naslijeđa vlastite regionalne obilježenosti, odnosno specifičnog kulturnog supstrata koji definira pripadnost antičkoj, mediteranskoj, uže shvaćeno, dalmatinskoj kulturnoj zajednici. Spomenimo u tom smislu samo dva ključna primjera, oličena imenima slikara Vjekoslava Paraća - koji, riječima Igora Zidića, iz povorki seljaka stvara kulturno, odnosno povijesno uvjetovane prikaze antičkih panatenejskih povorki ${ }^{13}$ - i kipara Andrije Krstulovića. Potonji će također u mediju sitne terakota-plastike iskoristiti prikaze preuzete iz ruralnog imaginarija. Radi se o stvarnim likovima vlaških pastira iz dalmatinskog zaleđa koje je kipar

9 Krešimir Nemec, Povijest hrvatskog romana od 1945. do 2000. godine, Zagreb 2003., 193.

10 Vladimir Rismondo, Zaustavljeno vrijeme, Split 1989.

11 Vladimir Rismondo, Oblici i slova, Split 1979., 15-16.

12 Toma Arhiøakon, Kronika, Split 1960.

13 Vjekoslav Parać. Umjetnički paviljon, Zagreb, travanj 1984. [katalog izložbe; autor izložbe Igor Zidić], Zagreb 1984. 
viđao na splitskom pazaru te koji su se u Krstulovićevoj dramatičnoj obradi „urbanizirali“ i preobrazili u protagoniste egzistencijalistički uvjetovanog, a ipak načelno antičkog mita o Edipu. ${ }^{14}$ Nema sumnje, Vladana Desnicu i Vladimira Rismonda s nabrojanim umjetnicima spaja upravo svijest o mogućnosti da se iz genius loci, mitskog i povijesnog imaginarija, izvuče autentična, tada suvremena egzistencijalistička pozicija. Zato će Rismondo biti u prilici 1963. godine napisati sljedeće o Vladanu Desnici:

Psiha Vladana Desnice (...) u svom intimnom tkivu je mediteranska jer je ona srodna psihi antičkih grčkih ljudi (...) Zato se Vladan Desnica može nazvati mediteranskim piscem, i, prema tome, i zadarskim i dalmatinskim. ${ }^{15}$

I nešto ranije:

U gluhoj samoći potkrovlja jedne dalmatinske kuće, u atmosferi straha koji stvaraju prašnjavi predmeti, dječak izvlači gudalom iz žica napuštene violine jedan jedini zvuk što stalno jednak odzvanja kroz bezglasni prostor. ${ }^{16}$

Više o promišljanju egzistencijalističke podloge mediteranizma vjerojatno nije moguće reći.

Zanimljivo je primijetiti kako jedan tako bogat i kompleksan odnos - kakav su imali Vladan Desnica i Vladimir Rismondo - ostaje popraćen razmjerno malim brojem materijalnih dokaza u vidu primarnih izvora nađenih u arhivu prof. Vladimira Rismonda. O razlozima smo uvodno govorili, a spomenuli smo također da se radi o tek osam dokumenata u vidu pisane korespondencije Desnice prema Rismondu. Ipak, i tako reducirani materijal upućuje na tri aspekta odnosa dvojice prijatelja. Prvi je, dakako, sveden na intimno razmjenjivanje informacija, uključujući i onih obiteljskih. U tom registru također saznajemo kako je Desnica sklon pismenoj komunikaciji a Rismondo nije, zbog čega Desnica višekratno, često i vrlo duhovito prekorava prijatelja. Drugi aspekt ove komunikacije tiče se kulturnih prilika u Splitu i Dalmaciji, čemu Vladan Desnica - sada situiran u Zagrebu - više ne može izravno svjedočiti, pa mu Rismondo ostaje bitnim izvorom informacija. Treći aspekt tiče se općeg društveno-ekonomskog konteksta, čemu ponajprije svjedoči pismo iz 1946. godine. Redom ćemo opisati svih osam pisama:

Pismo od 24. 8. 1946.

Pismo je napisano pisaćom mašinom u A4 formatu, obostrano, rukom potpisano. Desnica naručuje od Rismonda felgu za bicikl i žali se na tešku situaciju u Islamu Grčkom. Također spominje kompozitora Ivu Paraća i Sigmunda Stega kao istaknute članove predratnog splitskog kulturnog miljea. ${ }^{17} \mathrm{U}$ kontekstu teksta nalazimo i prvi zabilježeni prigovor zbog Rismondove aljkavosti u praćenju korespondencije.

14 V. Rismondo, Oblici i slova, 205-209.

15 V. Rismondo, Ljudi i slike Dalmacije, 190.

16 Isto, 188.

17 Ivo Parać (1890. - 1954.) bio je skladatelj, a od 1925. djeluje u Splitu kao učitelj glazbe, skladatelj i zborovođa. Skladao je scensku i instrumentalnu glazbu, ali posebnu je sklonost imao prema solo pjevanim dionicama i zborskoj glazbi. Paraćeva poznata opera Adelova pjesma nastala je prema libretističkom predlošku Bijedna Mara Luke Botića. Pjesme su mu okupljene u zbirci Ludi e canti. 

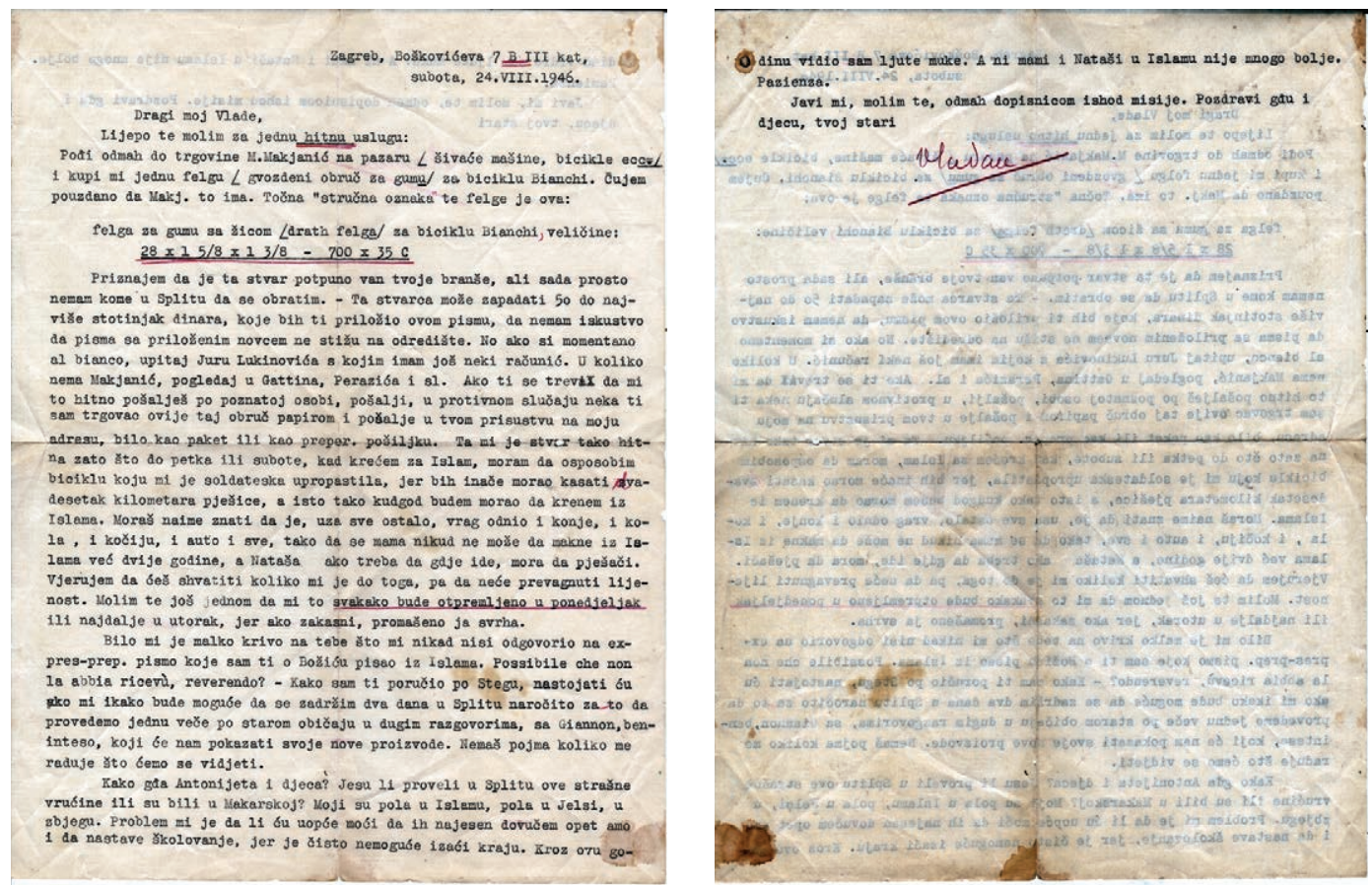

Sl. 2. Pismo Vladana Desnice Vladimiru Rismondu (24. kolovoza 1946.)

\section{Pismo od 18. 12. 1953.}

Pismo je napisano pisaćom mašinom u A5 formatu, obostrano, rukom potpisano. Desnica se jada zbog velike količine posla. Također spominje gđu. Madeleine Denegri, prevoditeljicu s francuskog jezika, kojoj šalje na ispravak prijevod jedne novele. ${ }^{18}$ Zove Rismonda u posjet, a potom žali zbog „crkavanja“ revije Književni Jadran. Nestajanje revije pripisuje nezdravim međuljudskim odnosima te izravno, imenom i prezimenom imenuje krivca, dodajući kako se radi o Splitu kao „degutantnoj sredini“. Konačno govori o svojim novim izdanjima te spominje Hranka Smodlaku i Ćiru Čičin Šaina. ${ }^{19}$

\section{Dopisnica od 29. 3. 1954.}

\section{Dopisnica je pisana rukom, formata $9 \times 14 \mathrm{~cm}$.}

Desnica spominje „gospođu“ (vjerojatno Madeleine Denegri) od koje još nije dobio vijesti, kao ni od Rismonda („od tebe ni mukajet“). Također pita je li „gospođa“ poslala prijevode dviju novela Guillouxu (vjerojatno se radi o Louisu Guillouxu, francuskom književ-

Sigmund Steg (rođ. 1904.) bio je istaknuti član splitskog kulturnog kruga prije Drugog svjetskog rata. Po završetku rata emigrira u Izrael, gdje biva aktivan u radu Udruženja Jevreja u Izraelu.

18 Madeleine Epron Denegri (1902. - 1989.) bila je francuska novinarka, a u razdoblju 1930. - 1936. i osobna tajnica André Gidea. Godine 1939. udaje se za prof. Milivoja Denegrija i ostaje živjeti u Splitu kao prevoditeljica s hrvatskog na francuski jezik te lektorica na Višoj pedagoškoj školi. Godine 1988. dobila je Zlatni grb Grada Splita.

19 Hranko Smodlaka (1900. - 1969.) bio je splitski publicist, pjesnik i scenski pisac. Bio je prvi dopisnik izvještajne agencije Tanjug u inozemstvu. a također je uređivao kratkotrajnu kulturnu reviju Književni Jadran, pokrenutu 1952. godine. Najpoznatije scensko djelo bila mu je drama Antipatra ili Krivi spoj iz 1963. godine.

Ćiro Čičin S̆ain (1890. - 1960.) bio je poznati splitski pjesnik, putopisac, prevoditelj i dramski pisac. Uređivao je niz listova, između ostalog i Novo doba, a u poslijeratnom razdoblju - kao ravnatelj Muzeja grada Splita (1947. - 1958.) - pokrenuo je Izdanja Muzeja grada Splita. 

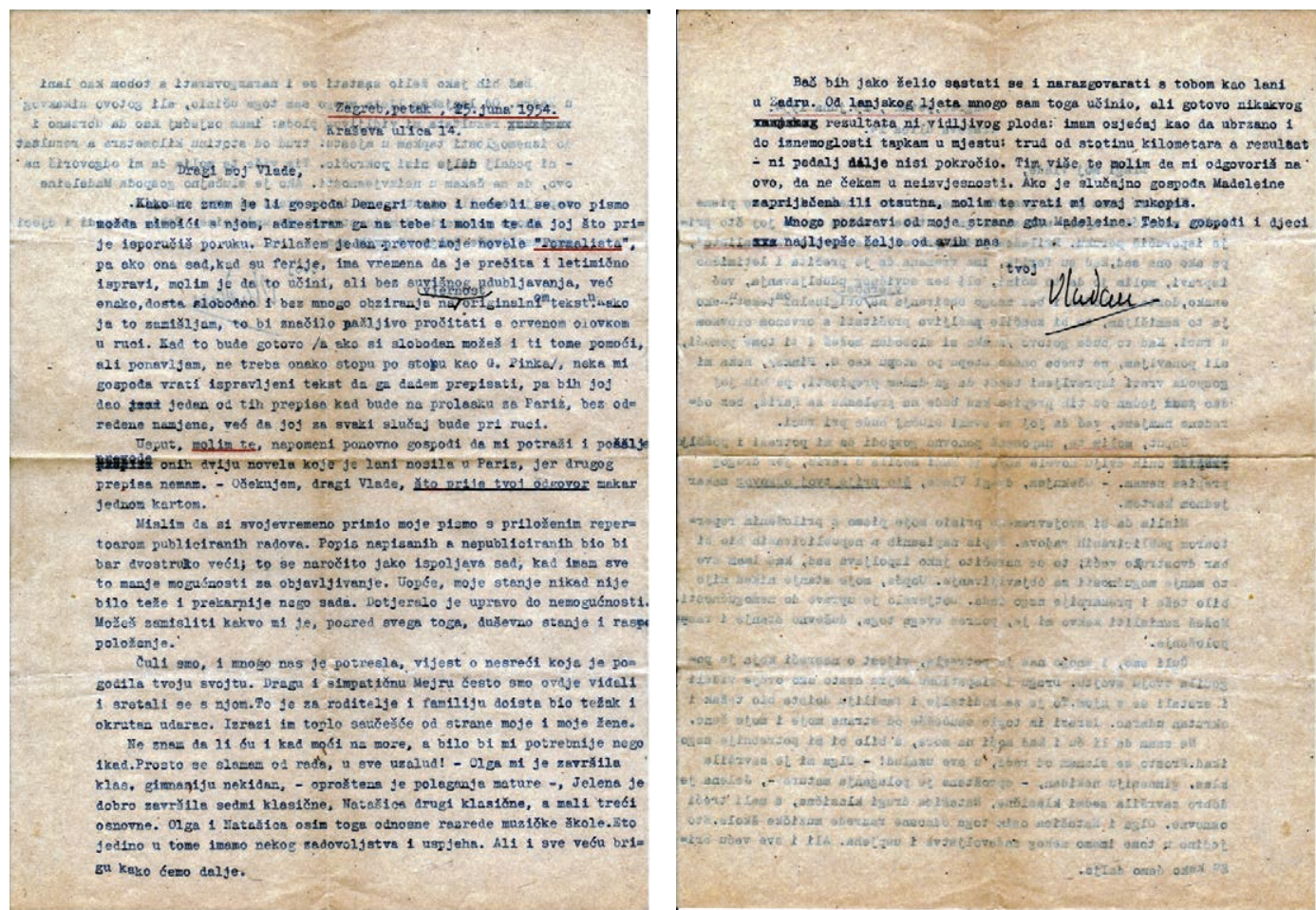

Sl. 3. Pismo Vladana Desnice Vladimiru Rismondu (25. lipnja 1954.)

niku, socijalističkom aktivistu te prijatelju Andréa Malrauxa i Alberta Camusa). Također piše kako se javio „P-u“, kojem zahvaljuje te čije je pričice preveo za francusko tržište.

Pismo od 25. 6. 1954.

Pismo je napisano pisaćom mašinom u A4 formatu, obostrano, rukom potpisano. Desnica spominje kako šalje nove prijevode na uvid gđi. Madeleine Denegri (usput moli Rismonda da nadzire proces prevođenja), a daje i kratki izvještaj o svojoj djeci. Izražava intimno žaljenje zbog nedostatka napretka u vlastitom radu te se dodatno žali na sužavanje mogućnosti objavljivanja. Desnica konačno očekuje od Rismonda „makar jednu kartu“, žarko priželjkujući sastanak i nastavak razgovora s prijateljem.

Dopisnica od 13. 9. 1954.

Dopisnica je adresirana rukom, formata 9x14 cm.

Tekst dopisnice sveden je na sažetu kritiku Rismondovog zanemarivanja pisane komunikacije te je na mjestu rezerviranom za tekst ispisan samo jedan jasno naznačeni znak pitanja.

\section{Pismo od 11. 4. 1955.}

Pismo je napisano rukom, formata $21 \times 11,8 \mathrm{~cm}$, jednostrano.

Radi se o dokumentu kojim Desnica potvrđuje kako se sprema na znamenito putovanje Pedagoške akademije u Grčku 1955. godine. Pisac pritom izražava zadovoljstvo što će na ekskurziju poći i Rismondo. Fotodokumentacija dokazuje Desničinu i Rismondovu nazočnost na putovanju 


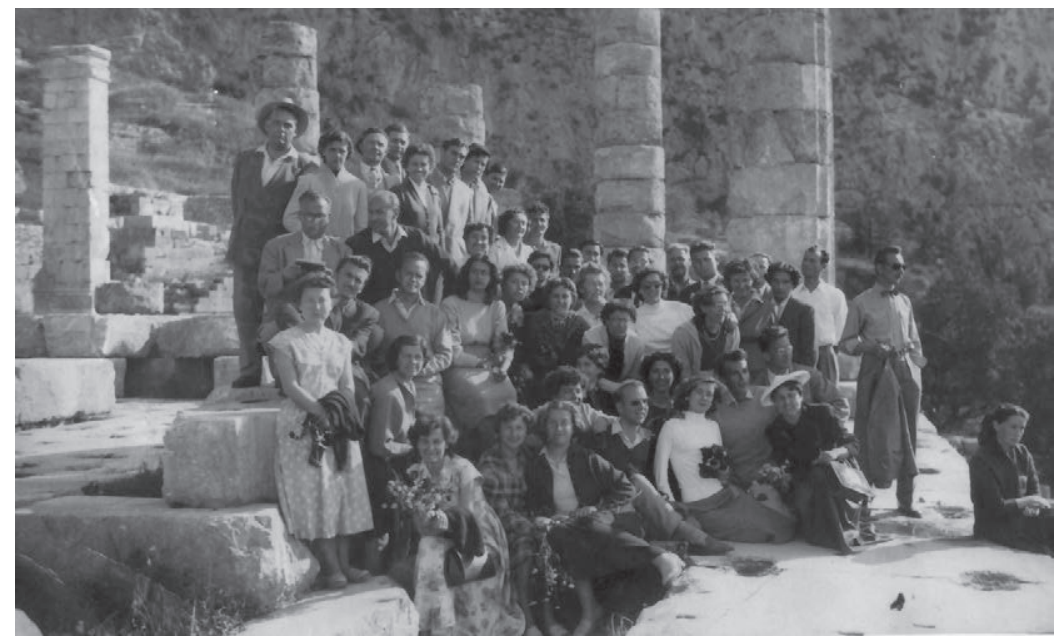

Sl. 4. Sudionici putovanja Pedagoške akademije u Grčku 1955. Vladan Desnica stoji prvi slijeva u gornjem redu.

Dopisnica od 22. 11. 1955.

Dopisnica je pisana rukom, formata 9x14 $\mathrm{cm}$.

Desnica se zahvaljuje na „knjizi i karti“ koje mu je Rismondo vjerojatno ranije poslao. Također spominje neko svoje neidentificirano djelo (s obzirom na dataciju dopisnice, možda je riječ o zbirci pripovijedaka Proljeće u Badrovcu) za koje od Rismonda očekuje „jedan strog i budan tamižamenat", odnosno bistrenje sadržaja.

Pismo od 14. 11. 1958.

Pismo je napisano pisaćom mašinom u formatu A5, jednostrano, rukom potpisano. Desnica od Rismonda potražuje Croceov tekst „Poesia e non poesia“ radi eventualnog prevođenja. Također izražava nuždu za tim poslom jer je - kako kaže - „na niskim granama“ pa se mora ispomagati prijevodima. Konačno isporučuje pozdrave Ćiri Čičin Šainu.

Nevelikom broju od osam primarnih, treba dodati i tri sekundarna izvora. Za početak se radi o tekstu stanovitog Antuna Grgičevića koji je - spremljen u otvorenoj poštanskoj omotnici - nađen u arhivu prof. Vladimira

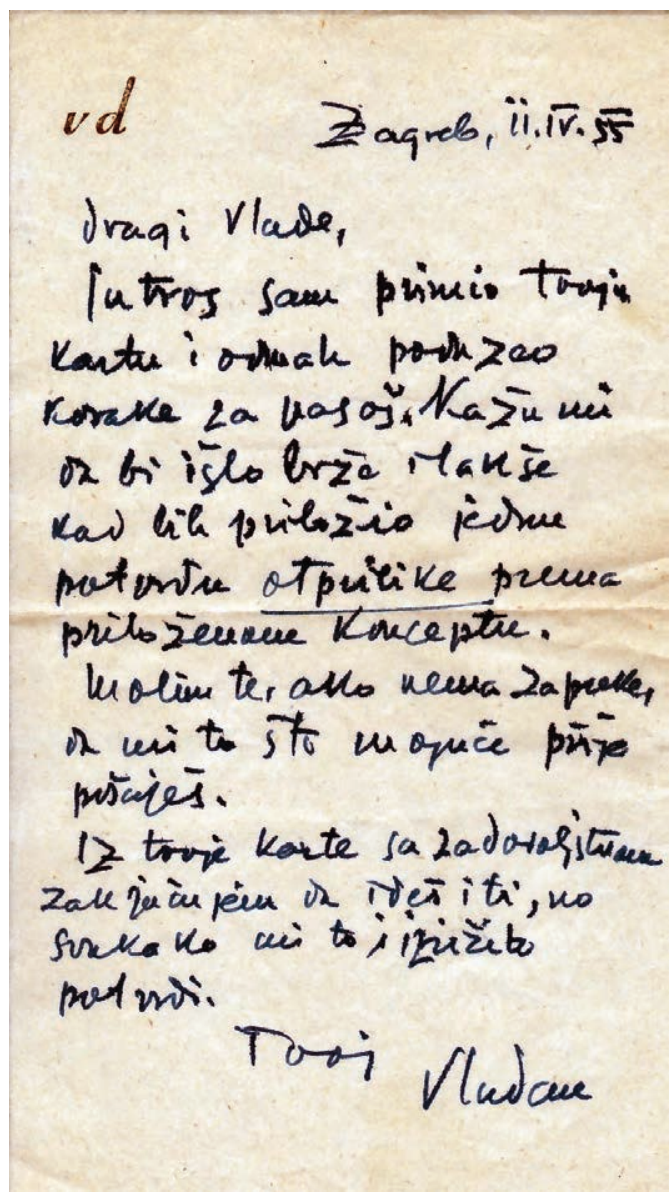

Sl. 5. Pismo Vladana Desnice Vladimiru Rismondu (11. travnja 1955.) 
Rismonda. Tekst datira iz 1935. godine, a omotnica je bila naslovljena „Odličnom gospodinu Vladanu Desnici, uredniku Magazina Sjeverne Dalmacije“. Grgičevićev tekst pod naslovom „Tragom za Ilirima“ gotovo sigurno je poslan u cilju izdavanja u okvirima Magazina Sjeverne Dalmacije. Radi se zapravo o pokušaju dokazivanja da sadašnji slavenski jezici na Balkanu ne mogu biti mlađi od albanskog i grčkog jezika. Time se u najmanju ruku potvrđuje kako je Magazin Sjeverne Dalmacije kod zainteresiranih autora bio percipiran kao revija posvećena istraživanju dalmatinskog identiteta na doista širokoj skali.

Drugi izvor u ovom kontekstu je bilježnica Hranka Smodlake - pokretača i urednika Književnog Jadrana - u kojoj je Smodlaka s jedne strane bilježio službene honorare suradnika, a s druge vodio osobno knjigovodstvo. Zanimljivo je, ali danas nemoguće rekonstruirati, kako je bilježnica uopće završila u Rismondovom posjedu. Jednako je zanimljivo pogledati pisaćom mašinom ispisan dokument nađen unutar bilježnice, s datumom od 19. rujna 1952. godine, koji poimence navodi suradnike u brojevima 7 i 8 revije Književni Jadran. Tu ćemo naći dobro poznata imena koja se provlače kroz poslijeratni splitski i dalmatinski kulturni milje: Šimu Vučetića, Vladana Desnicu, Srećka Dianu, Vladimira Rismonda, Ćiru Čičin Šaina i druge. Ipak, iz današnje je perspektive vjerojatno najzanimljivije pročitati opasku ispisanu nad samim spiskom autora: „Honorari obračunati su na osnovu najnižih dozvoljenih stavaka i onda još nešto smanjeni, sa pristankom autora“.

Treći izvor je povjesničaru i najintrigantniji. Radi se o separatu Zadarske revije iz 1954. godine, odnosno o tekstu Vladana Desnice s posvetom Vladimiru Rismondu. ${ }^{20}$ Tekst nosi naslov „O jednom gradu i o jednoj knjizi“, a radi se o Desničinoj obrani stavova impliciranih u romanu Zimsko ljetovanje. Knjiga je, naime, u agitpropovskoj maniri napadnuta od strane Jože Horvata, ali Desnica ističe kako je imala i vrlo dobrih recenzija (npr. od strane Aleksandra Tišme ili Čede Price). Pisac konačno ističe kako je - pišući o Zadru i njegovom zaleđu - zapravo dao pregled konstrukcije mediteranskog identiteta u vidu konflikta gradske agore i sela. ${ }^{21}$

Konačno, arhiv prof. Vladimira Rismonda nudi pregršt sasvim posrednih izvora koji potvrđuju njegovo prijateljstvo s Vladanom Desnicom i upućenost u Desničin rad. Tu, među ostalim stvarima, zasigurno spada i kratki dopis Aleksandra Tišme koji se Rismondu obraća u ime Letopisa Matice srpske te mu 1972. godine šalje broj Letopisa u kojem je obilježena petogodišnjica Desničine smrti. Tišma također podsjeća Rismonda na slanje nekog obećanog teksta o Desnici.

\section{ZAKLJUČAK}

Koliko god bili oskudni, materijali iz arhiva prof. Vladimira Rismonda svjedoče prije svega o prijateljstvu dvojice stvaralaca, a potom, mnogo važnije, pružaju uvjerljive dokaze postojanju kulturnog kruga dalmatinskih intelektualaca u periodu koji smo okvirno

\footnotetext{
20 Vladan Desnica, O jednom gradu i o jednoj knjizi (posebni otisak iz Zadarske revije, 3/1954., br. 1), Zadar 1954. 
odredili rasponom od 1918. do 1960. godine. Radi se o iznimno zanimljivoj i povezanoj grupaciji ljudi koja je objedinjavala nekoliko generacija. O njoj je vjerojatno najdojmljivije svjedočenje dao sam Vladimir Rismondo u intervjuu Vojku Mirkoviću za Nedjeljnu Dalmaciju od 20. 4. 1975..$^{22} \mathrm{U}$ tom tekstu prije svega nalazimo opis Splita prve četvrtine 20. stoljeća, Splita koji se sastojao od biranih primjera secesijske arhitekture, od Vidovićevog poentilizma koji se mogao naći u slikarevom atelijeru na vrhu kazališne zgrade, ali i od djelovanja mladih pro-južnoslavenskih intelektualaca. Bio je to Split Josipa Smodlake i Ante Trumbića, no u istom su kontekstu bili aktualni Tin Ujević, Vladimir Čerina, Jerolim Miše, Marino Tartaglija i drugi. Lista imena koja Rismondo nabraja doista je impresivna, a nastavlja se nešto mlađom generacijom angažiranih intelektualaca poput Antuna Zuppe, Ante Cettinea, Vjekoslava Paraća, Hranka Smodlake, kompozitora Ive Paraća te, dakako, i prije svih ostalih, Vladanom Desnicom. Većina spomenutih - potpomognuta likovnim umjetnicima poput Andrije Krstulovića, Milana Tolića ili Ante Kaštelančića - bit će među nositeljima kulturne identifikacije Dalmacije i u vremenu nakon Drugog svjetskog rata, odnosno sve do sredine sedmog desetljeća 20. stoljeća.

Važno je, naposljetku, u Rismondovom intervjuu uočiti i nametnutu političku notu koja je zbog regionalne dalmatinske orijentacije i njega i Vladana Desnicu pratila za života te ih - posebno Desnicu - na izvjestan način posmrtno još uvijek prati. ${ }^{23}$ Rismondo je u tekstu intervjua iz 1975. godine živo svjedočio o tome, navodeći napade iz revije Kritika s početka sedamdesetih, a koji su počivali na optužbi za „anti-hrvatstvo“, odnosno za političko dalmatinsko autonomaštvo. Rismondo, pak, nikada nije nijekao da je kao mladi angažirani intelektualac koji se formirao u vremenu pada Austro-Ugarske Monarhije vjerovao u (tada bez sumnje progresivno) kulturno jugoslavenstvo te da je već u četvrtom desetljeću 20. stoljeća počeo razmišljati o zasebnom regionalnom kulturnom identitetu Dalmacije, ali je uvijek - čak i u kasnijem slučaju predgovora prijevodu Kronike Tome Arhidakona - odbijao političke implikacije svojih uvjerenja. Ta su uvjerenja na svaki način ostala zabilježena u tekstu spomenutog intervjua, ali i - možda još sažetije - u nekrologu koji je Rismondo napisao neposredno po smrti Vladana Desnice. Ondje pisac govori o Desnici koji je:

(...) vrlo rano došao u dodir s filozofskom i historijskom misli Benedetta Crocea, a plod tih njegovih prvih dodira bili su prijevodi nekoliko Croceovih eseja iz estetike te prvih poglavlja njegove magistralne „Historije Evrope“. Štampajući „Eseje iz estetike“ Desnica se za oznaku izdavačkog poduzeća poslužio imenom Kadmosa, i ovo je ime, koje je bilo ime prvog grčkog legendarnog kolonizatora u dalmatinskom primorju, trebalo da simbolizira iskonsku i intimnu povezanost Dalmacije $s$ velikim žarištem civilizacije, kao što je veza s Croceovom filozofijom trebalo da služi njemu koji je duboko poznavao razvoj klasične i talijanske kulture u svima njihovim književnim i umjetničkim vidovima kao najprirodnija osnova za daljnja poniranja u razvoje velike svjetske filozofske misli, u koje se Croce na svoj talijanski i tradicionalistički način bio uključio. ${ }^{24}$

22 „Vraćanje tradiciji“, Nedjeljna Dalmacija (Split), br 206, 20. 4. 1975., 7.

23 O tome vidi u tekstu: Nikica Barić, „Vladan Desnica - novi prilozi za biografiju“, Pilar, 8/2013., br. 15-16, 9-67. Autor u tekstu dovodi obitelj Desnica, pa i samog Vladana Desnicu, u prisnu vezu s četničkim pokretom u Dalmaciji. Ovu konstrukciju - zasnovanu na posrednim dokazima, koji sa samim Vladanom Desnicom nemaju izravne, a kamoli utemeljene veze - bilo bi suvišno komentirati, pogotovo u kontekstu Desničinog kulturnog svjetonazora.

24 V. Rismondo, Oblici i slova, 211. 


\section{$\cos$}

\section{Vladan Desnica in the Family Archive Sources of Vladimir Rismondo Sr. in Split}

The family archive of historian and intellectual Vladimir Rismondo Sr. (Makarska, 11th September 1902 - Split, 8th January 1994) located in Split holds a multitude of fragmentary data on the persons and occurrences which shaped the cultural, political and economic history of Dalmatia in the nineteenth and twentieth centuries. One such person is the writer Vladan Desnica (Zadar, 17th September 1905 - Zagreb, 4th March 1967) who shared a profound friendship with Rismondo, as well as a notable part of his personal biography. Although the contacts between Desnica and Rismondo were often and varied, the Rismondo Split archive holds only eight letters and postcards sent by Desnica, along with some other documents of secondary importance. This paper notes and describes these sources, placing them in the intellectual context of the circle of "Croceans of Split" before the Second World War, or supporters of the "Dalmatian Mediterraneanism" idea after the war. The paper thus overcomes the confines of notes on archival documents which support the thesis of a friendship between the two intellectuals, and becomes an example of research into the cultural climate of Split and central Dalmatia from 1919 to 1960. The author looks into some political aspects implied by the idea of "Dalmatian Mediterraneanism", followed by both friends throughout their lives. Vladimir Rismondo had been attacked as a Dalmatian autonomist, and some still today fault Vladan Desnica for his Serbian origins, or family relations with the Chetnik movement. In conclusion, the author does not form an opinion based on these allegations, finding that the cultural orientation of Vladan Desnica, and Vladimir Rismondo Sr. - followed by a complete lack of political engagement - constitutes a worthy counter-argument.

Keywords: Vladan Desnica, Vladimir Rismondo Sr., family archive, Croceans of Split, Mediterraneanism, existentialism

\section{$\cos$}

\section{Literatura}

Toma ArhiĐakon, Kronika, Split 1960.

Nikica BArić, „Vladan Desnica - novi prilozi za biografiju“, Pilar, 8/2013., br. 15-16, 9-67.

Benedetto Croce, Eseji iz estetike, Split 1938.

Vladan Desnica, O jednom gradu i o jednoj knjizi (posebni otisak iz Zadarske revije, 3/1954., br. 1), Zadar 1954.

Magazin Sjeverne Dalmacije, 2/1935.

Krešimir Nemec, Povijest hrvatskog romana od 1945. do 2000. godine, Zagreb 2003.

Mirna Sindičić SABlJo, „Predodžbe o ruralnoj sredini u Zimskom ljetovanju Vladana Desnice“, Fluminensia, 23/2011., br. 1, 131-142.

Vjekoslav Parać. Umjetnički paviljon, Zagreb, travanj 1984. [katalog izložbe; autor izložbe Igor Zidić], Zagreb 1984.

Vladimir Rismondo, Ljudi i slike Dalmacije, Split 1964.

Vladimir Rismondo, Oblici i slova, Split 1979. 
Vladimir Rismondo, Zaustavljeno vrijeme, Split 1989.

„Vraćanje tradiciji“, Nedjeljna Dalmacija (Split), br 206, 20. 4. 1975., 7.

\section{Prilog}

\section{Marica Rismondo-Berket: Sjećanje na Vladana Desnicu}

André Malraux naša sjećanja na umjetnička djela koja smo na poseban način doživjeli, i ostala su nam u sjećanju, naziva našim imaginarnim muzejima. No, mi u sebi pohranjujemo i sjećanja na ljude koji se nečim posebno ističu i na naše kontakte s njima. U takvu moju „zbirku“ već u mojim vrlo mladim danima ušao je Vladan Desnica.

Desnicu i njegovu obitelj ne pamtim iz vremena kad su živjeli u Splitu jer sam tada bila u sasvim ranoj životnoj dobi. Moja prva sjećanja na njih sežu u poratne godine poslije Drugog svjetskog rata. Sjećam se posjeta njima u njihovu domu u Zagrebu u Kraševoj ulici (sada Bauerovoj) kamo me majka odvela kao djevojčicu. Desničini su ljeti dolazili u Dalmaciju, zadržavajući se u Splitu, najčešće na proputovanju za Jelsu. Desnica je katkad i sam dolazio u Split. Nastavljalo se njegovo davno započeto prijateljstvo s mojim ocem Vladimirom Rismondom, i mi u obitelji smo znali da, dok je Desnica u Splitu, otac ima „poseban režim života“; njih dvojica su svake večeri, do kasnih noćnih sati, provodili u šetnjama po već opustjelim ulicama grada, držeći se pod ruku (a kada bi ruka malko popustila, Desnica bi mu, onako usput, i dalje razgovarajući, podigao ruku u pravi položaj!). Na tim šetnjama vodili su se njihovi dugi razgovori. Jednom smo Desnicu slušali dok je govorio na svojoj Književnoj večeri u Splitu. No on je odjednom izašao iz „službenog diskursa“ pogledao je prema ocu koji je sjedio među publikom i upitao ga: „Sjećaš li se Vlade kada smo...?“ Vlade je kratko odgovorio: „Naravno, sjećam se.“ Ja više ne znam čega su se oni tada sjećali, ali Desnica je tih dana bio toliko uronjen u njihove razgovore da se i u tome času direktno obratio ocu!

Na povremenim večerama u našem obiteljskom domu, u ležernoj atmosferi, Desnica je bio veoma ugodan sugovornik. Elokventan, duhovit, široke kulture: na svaku asocijaciju u toku razgovora moglo se s njime otvoriti novu temu, uvijek je imao što reći. Ne treba reći kako se izražavao - pa bio je književnik! Imao je ugodan glas, vrlo izražajne oči, lijep osmjeh. Mome bratu i meni ostalo je i danas vrlo živo sjećanje na te večeri.

Moj prvi susret s Desničinom literaturom zbio se kad sam imala oko 15 godina - tada mu je objavljeno Zimsko ljetovanje, i pamtim ga kao meni vrlo dragu knjigu. Otprilike u to vrijeme otac me potaknuo da pročitam njegov prijevod s ruskog Tatjaninog pisma iz Evgenija Onjegina, objavljenog u listu Književni Jadran koji je tada izlazio u Splitu. Bio je to majstorski prijevod, uz izvanredno sačuvan duh originala, pročitala sam ga - i ponovo mu se vraćala.

Iz obiteljskog doma Desničinih, kamo sam povremeno dolazila u vrijeme mojih studija u Zagrebu i družila se s njihovim kćerima, sjećam se portreta predaka iz Islama Grčkog. Sjećam se stvaralačkog ugođaja Desničine radne sobe s bibliotekom. A uz rub radnog stola nalazilo se malo kuhalo, sa svime što je potrebno za kuhanje kave: to je bilo tu, očito, da mu pomogne kod noćnog rada. 
S Desničinim kćerima bila sam jedan ili dva puta u sobi koju su oni neko vrijeme bili zadržali u svojoj staroj kući na Tomića stinama u Splitu i u kojoj bi odsjeli. Pamtim da se tu, uz ostale stvari, nalazio i jedan klavir. Kada sam jednom otišla u Zadar, po želji mojih roditelja posjetila sam Desničinu sestru Natašu. U njenom skladno uređenom stanu prepoznala sam neke posebno izrađene lampe o kojima mi je otac pričao da ih je obitelj imala u Islamu Grčkom, a koje su njemu bile zanimljive zbog dizajna iz određene epohe. U svim tim ambijentima Desničinih koje sam upoznala osjećala se obiteljska tradicija, a neki predmeti svjedočili su o tome kako su pojedine generacije obitelji pratile ukus vremena.

Posljednji put vidjela sam Desnicu kada sam ga posjetila u Zagrebu, a to je bilo nekoliko mjeseci nakon smrti njegove supruge. Preda mnom je bio čovjek potpuno drugačiji od onoga koga sam poznavala. Bio je slika tuge - bez želje za razgovorom, pretužnih očiju. Imala sam osjećaj da se nalazim pred njim na sam dan pogreba gospođe Ksenije. Ovim istim riječima opisala sam susret $s$ njime mojim roditeljima nakon povratka u Split.

Otac je vrlo rijetko odlazio u Zagreb. Sjećam se da je tamo bio u kasno proljeće 1965. i tada je posjetio Desnicu. To je bio njihov posljednji susret - Desnica je umro nepune dvije godine nakon toga. Otac je otišao na njegov posljednji ispraćaj u Islam Grčki. Napisao mu je nekrolog. U tome tekstu prisjetio se njihovih druženja, posebno zajedničkih šetnji po Splitu u kasnim ljetnim večerima. Nadživio ga je gotovo 27 godina. Do kraja života stalno ga se prisjećao, mnogo pričao o njemu drugima, osobito mlađima koji ga nisu upoznali. Njihovo prijateljstvo ostavilo je trag u sačuvanoj korespondenciji, kao i u pojedinim očevim tekstovima i intervjuima.

Desničina kći Olga posjetila je oca 2-3 godine prije nego što je umro. Bio je to dug razgovor.

Generacije naših roditelja više nema, a susreti nas koji smo ostali iz naših dviju obitelji, nažalost rijetki, dodatno ožive moje sjećanje.

U Splitu 16. 9. 2014. Marica Rismondo-Berket 